\title{
ANALISIS EFEKTIVITAS PELAKSANAAN E GOVERNMENT DI TINGKAT KELURAHAN
}

\author{
Endah Mustika Ramdani \\ STIA-Lembaga Administrasi Negara Bandung \\ endahmustika@gmail.com
}

\begin{abstract}
Abstrak
Penelitian ini menganalisis praktek penyelenggaraan e-government pada lini terendah tata kelola pemerintahan yaitu tingkat kelurahan. Penelitian ini menggunakan metode deskriptif kualitatif. Selain itu dilakukan pula penelusuran melalui berbagai dokumen resmi pemerintah mupun pemberitan di media massa cetak maupun elektronik. Hasil penelitian menunjukkan bahwa e-government di tingkat kelurahan belum berjalan dengan efektif yang disebabkan oleh belum optimal nya penyediaan sarana prasarana e-government, efisiensi, kepuasan masyarakat, adaptasi aparatur terhadap aplikasi, pengembangan, dan kelangsungan hidup. Dengan adanya teknologi pemerintah menggunakan cara yang inovatif dalam berkomunikasi dengan masyarakat, kemudahankemudahan ini idealnya dapat meningkatkan kualitas pelayanan pemerintah dan memberikan kesempatan yang lebih besar kepada masyarakat untuk berpartisipasi dalam proses pelayanan publik dan mendukung keberhasilan smart city. Dengan demikian upaya yang dapat dilakukan antara lain dengan meningkatkan infrastruktur, pengembangan sumberdaya manusia dan menguatkan regulasi.
\end{abstract}

Kata Kunci: efektivitas, e-government, smart city

\begin{abstract}
This study aims to analyze the practice of the implementation of e-government at the kelurahan level as the lowest level of governance. This study employed the descriptive qualitative method. Besides that, the search through various official documents record, in print and electronic mass media was also conducted. The results of the study showed that the level of e-government at the kelurahan level has not run effectively due to the lack of optimal infrastructure provision, efficiency, community satisfaction, apparatus adaptation to application, development, and lifespan. With technology, the government is able to use innovative ways of communicating with communities, these facilities can ideally improve the quality of government services and provide greater opportunities for the public participation in public service processes to support smartcity. Therefore, there must be efforts to improve such obstacles which can be done by improving infrastructure, developing human resource and strengthening regulations.
\end{abstract}

Keywords : effectiveness, e-government, smart city

\section{A. PENDAhULUAN}

Pemerintah saat ini dihadapkan pada tantangan kebutuhan masyarakat yang menuntut adanya pelayanan efektif dan efisien melalui teknologi informasi dan komunikasi. Untuk menjawab kebutuhan tersebut pemerintah melakukan upaya dengan menyelenggarakan tata kelola kepemerintahan berbasis elektronik atau disebut dengan $e$ government. Tujuan awal adanya e- government adalah bagaimana pemerintah menggunakan teknologi informasi secara inovatif untuk memudahkan masyarakat dalam mengakses berbagai macam informasi dan layanan pemerintah. E-government juga bertujuan untuk meningkatkan kualitas pelayanan dan memberikan ruang partisipasi aktif kepada masyarakat dalam proses pemberian pelayanan prima. Pelayanan publik merupakan isu yang strategis karena 
menunjukkan komitmen dan keseriusan dari pemerintah kepada warganya, dimana masyarakat telah memberikan mandat kepada pemerintah untuk menggunakan pajak guna melayani kebutuhannya dalam rangka mewujudkan kesejahteraaan masyarakat. Hal tersebut membuktikan bahwa pemberian pelayanan publik yang berkualitas kepada masyarakat menjadi semakin penting untuk dilaksanakan.

Ketika memahami lebih lanjut mengenai e-government, ada tiga hal mendasar yang perlu diketahui yaitu bagaimana mengelola infrastruktur, memberikan solusi dan bagaimana mengembangkan portal publik yang sudah dibuat. Diperlukan infrasutuktur yang memadai dan sumber daya yang siap dalam menggunakan aplikasi e-government. Dibuatnya portal publik adalah untuk mengatasi isu-isu dan permasalahan di dalam tata kelola pemerintahan. Banyak keuntungan yang didapat oleh masyarakat ketika pemerintah memberikan akses untuk menggunakan portal publik diantaranya masyarakat menjadi lebih mudah mengakses pelayanan dan pelayanan yang diberikan oleh pemerintah dapat memenuhi kebutuhan masyarakat. Karena pada hakikatnya pengembangan teknologi informasi dalam tata kelola pemerintah diarahkan kepada bentuk teknologi baru berdasarkan logika atau "zero touch" dimana tidak ada lagi intervensi manusia dalam operasi administratif.(Buffat, 2015) Dengan adanya e-government pemerintah menggunakan cara yang inovatif dalam berkomunikasi dengan masyarakat, kemudahan-kemudahan ini idealnya dapat meningkatkan kualitas pelayanan pemerintah dan memberikan kesempatan yang lebih besar kepada masyarakat untuk berpartisipasi dalam proses pelayanan publik. Kehadiran teknologi informasi di dalam tata kelola pemerintah menjadi salah satu pendukung terwujudnya pemerintah yang bersih, transparan dan akuntable. Seperti definisi e-government menurut Bank Dunia (World Bank) bahwa $e$ government mengacu pada penggunaan oleh badan pemerintah teknologi informasi (seperti Wide Area Networks, Internet, dan mobile computing) yang memiliki kemampuan untuk mengubah hubungan dengan warga negara, bisnis, dan bidang pemerintahan lainnya (Indrajit, 2002)

Dengan adanya inovasi-inovasi melalui teknologi menunjukkan bahwa kemajuan teknologi memang memberikan manfaat yang sangat besar bagi kehidupan masyarakat di berbagai bidang. Salah satunya adalah pelayanan pemerintah kepada masyarakat di bidang kependudukan dan catatan sipil. Berbagai upaya ini merupakan pendukung terwujudnya Good Governance dimana Pemerintah, masyarakat dan swasta dapat bersinergi dalam mencapai tata kelola pemerintah yang baik. Disini pemerintah dituntut untuk meningkatkan kinerja, dengan memberikan pelayanan yang efektif, efisien dan berkualitas. Bagaimana pemerintah dapat meningkatkan dan mempercepat proses kerja, melalui e-government yaitu dengan membuat perubahan modern dalam penyelenggaraan pelayanan. E-government merupakan solusi dalam penyelenggaraan komunikasi dua arah antara masyarakat dengan pemerintah yang tujuannya untuk meningkatkan efisiensi, meningkatkan transparansi, meningkatkan kualitas kebijakan publik, serta untuk menciptkan hubungan baik antara pemerintah, masyarakat dn mewujudkan partisipasi masyarakat.(Song \& Guan, 2015)

Istilah e-government memberikan makna bahwa penggunaan teknologi saat ini merupakan sarana utama yang menggantikan media konvensional. Aplikasi e-government mulai dikenal semenjak munculnya perkembangan intenet dan menjadi fenomena yang mempengruhi semua aspek kehidupan manusia (Abu-Shanab, 2017). Pemanfaatan e-government di Indonesia ditujukan untuk mecapai perubahan kehidupan berbangsa dan bernegara secara fundamental, dari pemerintah yang sifatnya otoriter dan sentralistik menjadi pemerintah yang demokratis dan memperhatikan kewenangan pusat dan daerah. Perubahan tersebut 
menuntut adanya pemerintah yang transpran, bersih yang dapat memperpendek lini pengambilan keputusan serta memperluas rentang kendali.(Sosiawan, 2008) Egovernment di Indonesia dimulai sejak adanya Instruksi Presiden No. 6 Tahun 2001 tentang Telematika (Telekomunikasi, Media dan Informatika) yang menyatakan bahwa aparat pemerintah harus menggunakan teknologi informatika untuk mendukung Good Governance dan adanya intruksi Presiden RI No.3 Tahun 2003 tentang Kebijakan dan Strategi Nasional Pengembangan e-government. Semenjak adanya Intruksi Presiden tersebut, hampir seluruh daerah di Indonesia mulai mengembangkan e-government. (de Araujo \& Reinhard, 2013) Penggunaan TIK merupakan sarana untuk memperbaiki pengelolaan kegiatan pemerintah, proses administrasi, perumusan dan implementasi kebijakan, pengendalian kebijakan publik, sarana demokrasi serta sebagai penyedia layanan dari pemrintah kepada warganya seperti yang sudah dilakukan di Kota Bandung.

Kota Bandung sebagai salah satu kota di Indonesia yang serius mengembangkan program Smart City Indonesia telah membawa prestasi dalam pelayanan publik Kota Bandung berada pada peringkat ke empat nasional versi ombudsman. Pada November 2015 Kota Bandung terpilih menjadi salah satu kota yang masuk ke dalam kategori finalis Smart City 6 besar di Dunia dalam ajang inovasi Smart City dari World Smart city Organization di Barcelona.(Miftah, 2015) Kota Bandung terpilih menjadi salah satu kota Smart City karena beberapa keunggulan yang salah satunya adalah banyaknya ruang untuk warga bisa berinteraksi aktif dalam mengawasi pembangunan kota melalui inovasi. Dalam rangka mendukung program Smart City ini Walikota Bandung periode 2013-2018, melakukan beberapa upaya melalui programprogram unggulan, termasuk dalam bidang kependudukan dan catatan sipil yaitu dengan digunakannya program aplikasi $e$-kelurahan 151 kelurahan di Kota Bandung.

E-kelurahan merupakan 1 dari 300 aplikasi Smart City Kota Bandung yang sudah banyak diterapkan di Kota Bandung. Aplikasi $e$-kelurahan bersama dengan $e$-kecamatan merupakan program aplikasi yang merupakan bagian dari $e$-pemerintahan sebagai pendukung Smart City Kota Bandung. Tujuannya adalah untuk meningkatkan pelayanan yang digunakan dalam otomasi proses administrasi pelayanan masyarakat di Kantor Kelurahan secara, cepat akurat dan mudah. E-kelurahan sebagai program verifikasi berjenjang dalam bentuk aplikasi web memiliki tujuan untuk memudahkan aparatur pemerintah Kelurahan dalam membuat pengantar permohonan layanan dari masyarakat.Salah satu keunggulan penerapan e-government Kota Bandung termasuk $e$ kelurahan adalah program ini sudah memiliki perencanaan yang baik karena program $e$ government di Kota Bandung sudah dituangkan dalam RPJMD Kota Bandung. Dengan dituangkannya penerapan $e$ government dalam RPJMD merupakan langkah tepat pemerintah Kota Bandung dalam rangka mewujudkan pemberian administrasi pelayanan kepada masyarakat, serta mendukung pemanfaatan Teknologi Informasi dan Komunikasi (TIK).

Penguatan TIK di Kota Bandung merupakan strategi yang baik apabila melihat dari segi Karakteristik Kota Bandung. Ada 6 ciri utama dari Kota Bandung yang menjadi pilar kekuatan warganya. Apabila melihat rekapitulasi pemanfaatan TIK di lingkungan SKPD maupun Kecamatan dan Kelurahan Kota Bandung, berdasarkan data sekunder Diskominfo Kota Bandung bahwa prosentase SKPD dan Kecamatan/Kelurahan di Kota Bandung yang menerapkan pemanfaatan $e$ government terintegrasi sudah melampaui target. Namun dibalik keunggulan tersebut masih ada beberapa kendala yang dialami, seperti yang ditemukan pada observasi awal penelitian ini. Sampai saat ini server masih terus dalam pengembangan, masyarakat 
banyak yang belum mengetahui $e$-kelurahan, perangkat kelurahan di beberapa wilayah belum seluruhnya memahami $e$-kelurahan sehingga masih ditemukan adanya keluhankeluhan yang datang dari masyarakat terkait pelayanan di kelurahan. Begitu pula yang terjadi di kelurahan Manjahlega dimana belum seluruh jenis pelayanan menggunakan aplikasi $e$-kelurahan.

Di Indonesia sendiri sudah dilakukan beberapa penelitian terkait dengan penyelenggaraan e-government. (Hertiarani, 2016) meneliti mengenai kebijakan $e$ government samsat Jawa Barat dengan menggunakan metode kualitatif. Tulisan tersebut membahas bahwa perkembangan $e$ government terutama dalam peningkatan pelayanan kepada masyarakat memberikan manfaat yang besar bagi masyarakat salah satunya dalam memberikan pelayanan yang lebih responsive dan berorientasi kepada aspirasi masyarakat. Namun dari penyelenggaraan e-government samsat ini masih banyak masyarakat yang belum mengetahui dan memahami proses $e$ government samsat. Penelitian lain juga pernah dilakukan mengenai Street-Level Bureaucracy and E-Government bahwa dalam penyelenggaran e-government masih ditemukan fenomena ketidakmampuan sumberdaya aparatur, adanya tujuan kebijakan yang ambigu, serta tidak optimalnya pengendalian manajerial menjadi alasan mengapa sampai saat ini keinginan pemerintah untuk mengoptimalkan $e$ governement belum dapat terpenuhi.(Buffat, 2015). Penelitian lain menemukan bahwa tingkat kepercayaan pada pemerintah sangat terkait dengan pelayanan elektronik yang lebih intensif. Tingkat kepercayaan dari masyarakat kepada pemerintah akan mendorong penggunaan e-government, beberapa studi mengamati hubungan antara kepercayaan dalam penggunaan e-government dan ditemukan bahwa kepercayaan kepada pemerintah terkait pelayanan elektronik yang intensif sangat diperhatikan. Bahkan kepercayaan kepada pemerintah lebih penting daripada kepercayaan pada teknologi. Tetapi yang ada saat ini adalah masyarakat lebih mudah mempercayai aspek fungsional $e$ government yaitu teknologi dibandingkan percaya kepada penyedia layanan yang sebenarnya.(Nam, 2014) Selain itu dalam implementasi e-government sangat terkait dengan ketidakpastian, ketidakpstian ini terjadi ketika persepsi individu tidak mampu memprediksi lingkungan teknologi seperti ketidakpastian tugas, alur kerja, dan ketidakpastian lingkungan.(Venkatesh, Thong, Chan, \& Hu, 2016)

Dari penelitian tersebut menunjukkan bahwa penyelenggaraan e-government di beberapa daerah belum dipahami betul oleh masyarakat dan pemerintah. Melihat fakta ini perlu adanya komitmen dari pemerintah untuk mewujudkan e-government yang efektif di tengah beragamnya respon masyarakat akan teknologi informasi. Efektifitas penyelenggaraan e-government perlu menjadi perhatian sampai lini terendah pada tata kelola pemerintahan. Efektivitas e-government terkait dengan hubungan antara hasil yang diharapkan dengan hasil yang dicapai. Konsep ideal e-government yang telah dibuat oleh pemerintah daerah dengan upaya maksimal tidak dapat mencapai efektivitas ketika pemerintah pelaksana e-government dan masyarakat pengguna belum bisa beradaptasi dengan perubahan seperti yang penulis temukan pada penerapan e-kelurahan di Kota Bandung. Efektivitas dapat dilihat dari berbagai sudut pandang dan dapat dinilai dengan berbagai cara dan mempunyai kaitan yang erat dengan efisiensi. Seperti yang dikemukakan oleh (Gedeian, 1991) bahwa semakin besar pencapaian tujuan-tujuan organisasi semakin besar efektivitas.

Efektivitas penerapan e-government dapat dilihat apakah pelaksanaan suatu tugas dinilai baik atau tidak, penyelesaian pekerjaan tepat pada waktu yang telah ditetapkan atau sebaliknya. Definisi efektivitas yang digunakan dalam tulisan ini adalah sebagai tingkat pencapaian organisasi atas tujuan jangka pendek (tujuan) dan jangka panjang 
(cara). Pemilihan itu mencerminkan konstituensi strategis, minat mengevaluasi, dan tingkat kehidupan organisasi Robbins dalam (Indrajit, 2002). Efektivitas menurut (Gibson, James L; Ivancecih, John M.; Donnelly, 1996) memiliki 6 dimensi. Pertama Produksi, merujuk pada ukuran keluaran utama organisasi. Ukuran ini berhubungan secara langsung dengan yang pengguna pelayanan oleh masyarakat. Kedua, Efisiensi sebagai kriteria efektivitas mengacu pada ukuran penggunaan sumberdaya yang langka oleh organisasi serta penggunaan infrastruktur. Ketiga, Kepuasan yang merujuk kepada keberhasilan organisasi dalam memenuhi kebutuhan anggota organisasi, masyarakat dan stakeholder. Keempat, adaptasi yang merujuk pada seberapa jauh organisasi menanggapi perubahan internal dan eksternal. Kelima, Pengembangan merujuk pada tanggapan organisasi terhadap perubahan eksternal dan internal. Serta Keenam adalah Kelangsungan hidup yang mengacu mengacu kepada tanggung jawab organisasi/perusahaan dalam memperbesar kapasitas dan potensinya untuk berkembang. Berdasarkan latar belakang tersebut tulisan ini ingin mengkaji lebih dalam mengenai efektivitas e-government ditinjau dari aspek produksi, efisiensi, kepuasan, pengembangan serta kelangsungan hidup e-government di Kelurahan Manjahlega Kecamatan Rancasari Kota Bandung.

\section{B. METODE PENELITIAN}

Penulis menggunakan pendekatan kualitatif dilihat dari fenomena masalah yang ingin dikaji dengan metode studi kasus, dimana sebelum melaksanakan pengumpulan data, peneliti memulai dengan teori-teori yang spesifik dalam merumuskan hipotesis kerja. Adapun metode yang digunakan dalam tulisan ini adalah deskriptif - analitis. Pemilihan pendekatan kualitatif untuk menjawab masalah yang diajukan, lebih ditekankan adalah bagaimana memahami efektivitas penerapan e-kelurahan di Kantor Kelurahan Rancasari Kecamatan Majahlega Kota
Bandung serta untuk mengungkapkan dan memahami kendala-kendala yang dialami dalam pelaksanaan e-kelurahan di Kantor Kelurahan Rancasari Kecamatan Majahlega Kota Bandung.

Informan dipilih menggunakan teknik purposive, sebanyak 5 (lima) informan diantaranya, Plt Seksi Pelayanan Kecamatan Rancasari, Plt Seksi Pelayanan Kelurahan Manjahlega, Analis Kelurahan Bagian Pemerintahan Umum Kota Bandung, Operator e-kelurahan, Warga kelurahan Manjahlega.Teknik analisis data dilakukan sejak awal data dikumpulkan agar dapat diketahui kekurangan dan kelemahan data, triangulasi, reduksi data, ketegorisasi data penentuan dan perguliran informan. Data yang terkompilasi kemudian diolah melalui kegiatan Memproses, pengolahan data dimulai dengan menelaah seluruh data yang tersedia dari berbagai sumber baik hasil pengamatan maupun wawancara. Kemudian membuat rangkuman dari catatan lapangan, yang terdiri atas catatan pengamatan, catatan teori dan catatan metodologis. Kategorisasi yakni menentukan kategori atas dasar pikiran, intuisi, pendapat atau kriteria tertentu terhadap data yang diperoleh dan selanjutnya menempatkan data pada kategorinya masingmasing.

Pengujian data dilakukan untuk menguji keabsahan data yang dilakukan menggunakan teknik triangulasi, yaitu: check, recheck dan cross check terhadap data yang diperoleh. Triangulasi adalah teknik pemeriksaan keabsahan data yang memanfaatkan sesuatu yang lain di luar data tersebut demi keperluan pengecekan atau sebagai pembanding data (Moleong, 2001). Data yang telah dikumpulkan dihubungkan dan diuji dengan kategori yang telah ditetapkan. Selanjutnya dapat ditafsirkan dengan menghubungkannya dengan konsep atau teori yang ada. Hasil wawancara dengan informan berupa rekaman suara di transkripsikan ke dalam tulisan yang kemudian dipilah sesuai pengelompokkan 
informan yang akan di tuangkan ke dalam deksripsi analisis.

\section{HASIL PENELITIAN DAN PEMBAHASAN \\ Hasil Penelitian \\ Sistem Aplikasi $E$-Kelurahan}

Aplikasi $e$-kelurahan adalah

digitalisasi pelayanan yang digunakan untuk otomasi proses administrasi pelayanan masyarakat di Kantor Kelurahan secara, cepat akurat dan mudah. Aplikasi $e$-kelurahan ini merupakan salah satu aplikasi dari 100 aplikasi lain yang mendukung program Smart City Bandung. E-kelurahan memiliki beberapa tujuan diantaranya Pertama, mempercepat dan memudahkan pelayanan kepada masyarakat dalam pengurusan surat surat. Kedua, transparansi pelayanan masyarakat, terutama dalam proses pengajuan surat. Ketiga, adanya kepastian waktu pembuatan pelayanan persuratan, Keempat, keamanan data yang di simpan di Data Center dengan Cloud System dan ini sangat mendukung dalam rangka membangun pemerintahan Good Corporate Governance.

Sejak pertama kali muncul pada Tahun 2013 aplikasi $e$-kelurahan sudah banyak memberikan manfaat kepada masyarakat Kota Bandung untuk mempermudah tata kelola pemerintahan dan mempermudah segala urusan administrasi dari tingkat kelurahan. Sebanyak 151 Kelurahan di Kota Bandung sudah melakukan Mou dengan PT. Telkom Terkait program $e$ kelurahan. Aplikasi e-kelurahan menggunakan media Cloud Computing yaitu gabungan pemanfaatan teknologi komputer (komputerisasi) dalam suatu jaringan dengan pengembangan berbasis internet yang mempunyai fungsi untuk menjalankan program atau aplikasi melalui komputerkomputer yang terkoneksi pada waktu yang sama. Cloud computing merupakan gabungan pemanfaatan teknologi komputer dan pengembangan berbasis Internet. Cloud computing memiliki beberapa kelebihan dan kekurangan. Kelebihan dari cloud computing, yaitu diantaranya adanya Kemudahan akses karena untuk mengerjakan suatu pekerjaan, pengguna dapat mengakses dari mana saja dan kapan saja dengan syarat terhubung dengan Internet, Penghematan karena dengan adanya sistem cloud computing memungkinkan untuk mengurangi infrastruktur komputer yang memerlukan biaya pengadaan dan perawatan cukup besar, hal ini juga berarti staf IT yang diperlukan tidak terlalu banyak, dan staf IT yang ada tidak terlalu berurusan dengan update, konfigurasi dan hal-hal lain yang berkaitan dengan komputasi. Dengan adanya cloud computing, pengguna juga tidak dihadapkan dengan beban biaya untuk membayar lisensi atas software-software yang diinstal dan digunakan, karena semua software sudah bisa digunakan melalui cloud computing. Ketika aplikasi ini dibuat sebetulanya sudah dirancang agar memudahkan seluruh komponen masyarakat dalam mengkases informasi, karena dengan system Web Base Application pentium 4 aparat kelurahan dipastikan tidak akan mengalami kendala jaringan karena aplikasi ini bisa dibuka di media baik PC, laptop.

Dengan adanya aplikasi $e$-kelurahan, turut mendukung pencapaian efektivitas dan efisiensi dalam pemberian pelayanan kepada masyarakat di tingkat kelurahan. Efisiensi disini artinya aparatur kelurahan mampu menyelenggarakan pelayanan dengan lebih murah, mampu menjangkau lebih banyak lapisan masyarakat, dan mampu bekerja lebih cepat. Sedangkan efektivitas merujuk pada kemampuan aparatur Kelurahan untuk bekerja lebih baik dan lebih inovatif. Ini artinya aparatur kelurahan mampu menghasilkan output yang bahkan lebih berkualitas, dengan biaya dan waktu yang relatif sama.

\section{$e$-Kelurahan Majahlega Kecamatan Rancasari}

Dari 151 Kelurahan di Kota Bandung, Kelurahan Manjahlega Kecamatan Rancasari Kota Bandung merupakan salah satu kelurahan yang mendukung adanya aplikasi e- 
kelurahan ini. Berikut adalah alur proses penggunaan aplikasi $e$-Kelurahan di Kota Bandung :

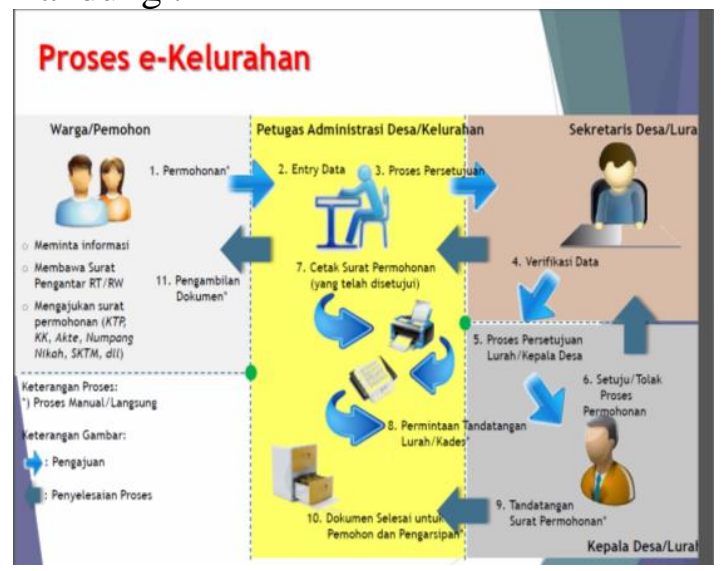

Gambar 1 Alur $e$-Kelurahan

Sumber : Tutorial $e$-kelurahan Kota Bandung

(Bagian Pemum Kota Bandung 2016)

Gambar alur e-kelurahan tersebut menunjukkan bahwa proses pelayanan diawali dengan pengajuan permohonan dari warga serta membawa syarat-syarat yang diperlukan, dan selanjutnya operator kelurahan melakukan input data warga sesuai dengan permintaan layanan yang dibutuhkan. Proses pengajuan permohonan dapat dilakukan apabila seluruh tahapan alur dilalui, termasuk tahap verifikasi oleh sekretaris dan lurah, pencetakan surat dengan barcode, sampai dengan dokumen diberikan kepada warga.

Berdasarkan mekanisme $e$-kelurahan tersebut, segala proses permohonan pelayanan yang diajukan oleh masyarakat harus dilalui sesuai dengan urutan dan persyaratan yang ditentukan. Di dalam tampilan aplikasi $e$ kelurahan informasi utama yang tersedia yaitu Dashboard dan Buat Surat. Dashboard adalah tampilan awal pada saat pertama kali operator log-in ke aplikasi e-kelurahan. Pada halaman ini dtampilkan rekapitulasi jumlah dokumen yang diterbitkan setiap bulan. Di dalam dashboard ini ada pula informasi mengenai rencana kegiatan kelurahan. Tidak hanya untuk aparatur kelurahan, warga pun bisa melakukan cek surat yang telah mereka ajukan dan tahapan proses pembuatan surat permohonan yang diajukan.

Menu lainnya pada aplikasi $e$ kelurahan adalah menu Buat Surat. Menu Buat Surat ini adalah menu utama yang mengakomodir pembuatan surat permohonan dari warga. Ada 9 pilihan utama layanan pembuatan surat melalui aplikasi $e$-kelurahan diantaranya Registrasi Surat, Surat Keterangan Domisili, Surat Keterangan Tidak Mampu, Surat Keterangan, Pengantar RT/RW, Surat Keterangan Kelahiran, Surat Keterangan Kematian, Surat Pengantar dan Template Dokumen. Selain menu Buat surat juga terdapat Data Surat, Menu ini berisi tentang data surat-surat yang sedang diproses maupun selesai diproses menggunakan $e$ kelurahan, Daftar Surat Menunggu Persetujuan menu yang digunakan untuk menyetujui surat-surat yang diajukan oleh masyarakat, Jadwal Pekerjaan yaitu menu yang berisikan data kegiatan-kegiatan kelurahan, Data warga yaitu menu yang berisi semua data lengkap warga (hanya user yang diberikan hak akses untuk dapat menambah data warga), serta Laporan Statistik yaitu fitur rekapan data warga untuk masing-masing nilai.

\section{Faktor-faktor yang mempengaruhi efektivitas penerapan $e$-Kelurahan di Kantor Kelurahan Manjahlega Kecamatan Rancasari Kota Bandung}

Untuk mengetahui sejauhmana efektivitas penerapan $e$-kelurahan di Kantor Kelurahan Manjahlega Kecamatan Rancasari Kota Bandung penulis menggunakan indikator efektivitas menurut (Gibson, James L; Ivancecih, John M. ; Donnelly, 1996) yaitu produksi, efisiensi, kepuasan, keadaptasian, dan kelangsungan hidup. Indikator-indikator ini sesuai dengan karakteristik $e$-kelurahan yang didalamnya syarat akan inovasi dan keberlanjutan. Oleh karena itu kelima indikator menurut Gibson tersebut dianalisis berdasarkan hasil wawancara yang dilakukan kepada Informan dan berdasarkan Data Sekunder yang ada. 


\section{Produksi pelayanan $e$-Kelurahan}

Produksi mencerminkan kemampuan organisasi dalam menghasilkan sejumlah barang/jasa sebagai tuntutan dari lingkungan. Ukuran ini berkaitan langsung dengan output yang digunakan oleh pengguna jasa dan stakeholder. Produksi dalam aplikasi $e$ kelurahan di Kantor Kecamatan Manjahlega merujuk kepada volume pelayanan $e$ kelurahan dan keakuratan output dokumen $e$ kelurahan. Tujuan awal dibuatnya aplikasi $e$ kelurahan adalah untuk mendukung pelaksanaan tertib administrasi tata kewilayahan di tingkat Kelurahan. Kelurahan sebagai ujung tombak pelayanan kepada masyarakat di wilayah perkotaan diharapkan mampu memberikan pelayanan kepada masyarakat sesuai dengan perkembangan dan kemajuan teknologi yang ada. Produksi dalam pelayanan $e$-kelurahan di Kantor Kelurahan Manjahlega dijelaskan dalam hasil wawancara penulis kepada Plt Kepala Seksi Pelayanan Kantor Kelurahan Manjahlega yang menjelaskan bahwa :

“ Aplikasi e-kelurahan di Manjahlega sudah berjalan sejak dilakukan Mou dengan Telkom. Beberapa pelayanan sudah kami selesaikan dengan aplikasi $e$-kelurahan. Produk pelayanan yang dihasilkan dari aplikasi $e$-kelurahan di Manjahlega diantaranya SKTM, Kartu Keluraga, Pindah Datang, KTP dan surat keterangan lainnya. Pada umumnya fitur pelayanan di setiap kelurahan sama, namun kami juga diberi kesempatan untuk mengatur fitur custom sesuai dengan kebutuhan di kelurahan masing-masing." (Hasil wawancara 10 November 2016)

Hal yang berbeda diungkapkan oleh salah seorang warga Kelurahan Manjahlega. Beliau mengungkapkan bahwa : "Saya mengetahui sekarang sudah ada program $e$ kelurahan menurut saya dari segi waktu penyelasaian sudah ada perubahan kalau dibandingkan dengan pelayanan manual, namun masih ada beberapa pelayanan yang terlambat seperti ketika ingin merubah informasi di Kartu Keluarga. Namun kelebihannya adalah data informasinya sudah akurat." (Hasil wawancara 11 November 2016)

Berikut adalah rekapitulasi pelayanan $e$-kelurahan di Kantor Kelurahan Manjahlega Tahun 2016 :

\section{Tabel 1}

Rekapitulasi Pelayanan $e$-kelurahan Manjahlega

Periode Januari s/d November 2016

\begin{tabular}{|c|c|c|}
\hline No & Jenis Pelayanan & Jumlah \\
\hline 1 & $\begin{array}{l}\text { Registrasi Surat (Permohonan } \\
\text { KK, Ahli Waris, Pertanahan, } \\
\text { Pensiunan, Pindah Keluar, } \\
\text { Pemberitahuan Tetangga untuk } \\
\text { IMB, KTP, Pindah Datang) }\end{array}$ & 1756 \\
\hline 2 & $\begin{array}{l}\text { Surat Keterangan Domisili ( } \\
\text { SK Domisili Organisasi/LSM, } \\
\text { SK Domisili Yayasan/Koperasi, } \\
\text { SK Domisili Sementara) }\end{array}$ & 54 \\
\hline 3 & $\begin{array}{l}\text { Surat Keterangan } \\
\text { Mampu ( SKTM Kesehatan, } \\
\text { Mamp } \\
\text { SKTM PBB, SKTM PMKS, } \\
\text { SKTM Pendidikan) }\end{array}$ & 170 \\
\hline 4 & $\begin{array}{l}\text { Surat Keterangan ( SK Biodata } \\
\text { Kependudukan, SK Kelakuan } \\
\text { Baik, SK Usaha, SK Belum } \\
\text { Mempunyai Rumah, SK Belum } \\
\text { Menikah) }\end{array}$ & 275 \\
\hline 5 & $\begin{array}{l}\text { Surat Keterangan Kelahiran } \\
\text { (Surat Kelahiran Kurang dari } 60 \\
\text { Hari, Surat Kelahiran Lebih dari } \\
60 \text { Hari) }\end{array}$ & 264 \\
\hline 6 & $\begin{array}{l}\text { Surat Keterangan Kematian } \\
\text { (Surat Kematian Kurang dari } 30 \\
\text { Hari, Surat Kematian Lebih dari } \\
\text { 30 Hari) }\end{array}$ & 127 \\
\hline 7 & $\begin{array}{l}\text { Surat Pengantar } \quad \text { (Surat } \\
\text { Pengantar Numpang Akad) }\end{array}$ & 304 \\
\hline \multicolumn{2}{|c|}{ TOTAL } & 2950 \\
\hline
\end{tabular}

Sumber : Data Kelurahan Manjahlega 2016

Berdasarkan hasil wawancara peneliti dengan informan, $e$-kelurahan Manjahlega sudah berjalan walaupun belum semua jenis pelayanan dilakukan dengan aplikasi ini. Penggunaan aplikasi $e$-kelurahan dirasakan ada perubahan dari proses manual, terutama 
dari segi waktu penyelesaian. Keunggulan lain dari penerapan $e$-kelurahan adalah bertambahnya tingkat keakuratan pada output pelayanan. Hal ini dikarenakan aplikasi $e$ kelurahan digunakan sebagai portal data dimana data masyarakat yang diinput ke dalam $e$-kelurahan digunakan sebagai basis data yang nantinya dapat digunakan pula ketika masyarakat ingin melakukan pelayanan lain dan digunakan sebagai data informasi kependudukan yang valid di tingkat kelurahan. Sampai dengan November 2016 aplikasi $e$-kelurahan telah digunakan oleh aparatur kelurahan Manjahlega untuk pemberian pelayanan kepada masyarakat. Dari rekapitulasi yang ada, total pelayanan yang dilakukan dengan menggunakan aplikasi $e$-kelurahan adalah 42 pelayanan. Berikut adalah tabel rekapitulasi e-kelurahan Manjahlega per November 2016 :

\section{Tabel 2}

\section{Rekapitulasi Permohonan Pelayanan Surat} $e$-kelurahan Manjahlega per Bulan

\begin{tabular}{l|c|c|c}
\hline$\underline{\text { Penduduk }}$ & $\underline{\underline{\text { Laki- }}}$ & $\underline{\underline{\text { Perempuan }}}$ & $\underline{\underline{\text { Jumlah }}}$ \\
\hline Lahir & 11 & 3 & 14 \\
\hline Meninggal & 11 & 3 & 14 \\
\hline $\begin{array}{l}\text { Pindah } \\
\text { datang }\end{array}$ & 0 & 0 & 0 \\
\hline $\begin{array}{l}\text { SKTM } \\
\text { Kesehatan }\end{array}$ & 11 & 3 & 14 \\
\hline TOTAL & $\mathbf{3 3}$ & $\mathbf{9}$ & $\mathbf{4 2}$ \\
\hline
\end{tabular}

Sumber : Data Bagian Pemerintahan Umum Kota Bandung 2016

Dari tabel 2 dapat terlihat bahwa untuk rata-rata permohonan pelayanan per bulan ada 42 jenis pelayanan yang dilakukan dengan menggunakan aplikasi kelurahan. Apabila dibandingkan dengan rekapitulasi data Seksi Pelayanan Kelurahan Manjahlega halaman sebelumnya, terdapat total pelayanan sebanyak 2.950 permohonan, ini artinya belum semua jenis pelayanan surat menggunakan aplikasi $e$-kelurahan. Untuk memperkuat data tersebut penulis melakukan wawancara kepada Analis Kelurahan Bagian Pemerintahan Umum Kota Bandung yang menjelaskan bahwa :" Seluruh kelurahan di Kota Bandung sudah menggunakan aplikasi $e$-kelurahan, namun memang masih ada beberapa kelurahan yang belum menerapkan aplikasi tersebut dengan maksimal. Setiap harinya kami bisa memantau laporan statistik pelayanan $e$-kelurahan di Kota Bandung melalui aplikasi ini. Dari fitur statistik seluruh kelurahan kami dari Bagian Pemerintahan Umum bisa melihat berapa banyak volume pelayanan di setiap kelurahan. "(Hasil Wawancara 25 November 2016)

Bagian pemerintahan umum Kota Bandung sebagai leading sector dari penerapan aplikasi $e$-kelurahan di seluruh Kota Bandung selalu berupaya melakukan pemantauan kepada seluruh Kelurahan untuk keberlangsungan aplikasi tersebut. Seperti yang terlihat dalam screenshot berikut ini :

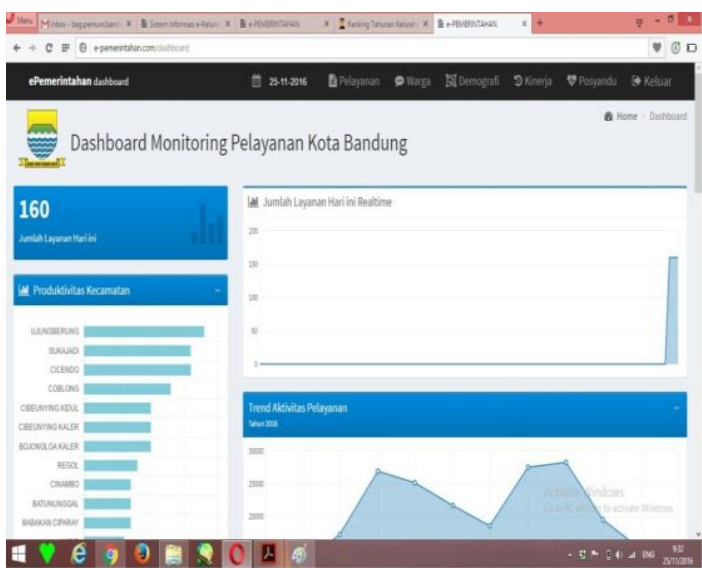

\section{Gambar 2 \\ Dashboard Monitoring Pelayanan Kota Bandung Per Kecamatan}

Sumber : Data Bagian Pemerintahan Umum Kota Bandung 2016

Gambar 2 menunjukkan bahwa Rekapitulasi pelayanan $e$-kelurahan harian per Kecamatan pada tanggal 25 November 2016 pukul 10.00 WIB, 10 urutan pertama berada pada Kecamatan Ujung Berung, Sukajadi, Cicendo, Coblong, Cibeunying Kidul, Cibeunying Kaler, Bojongloa Kaler, Regol, Cinambo, dan Batununggal. Sedangkan Kecamatan Rancasari yang merupakan wilayah Kelurahan Manjahlega tidak masuk 
urutan 10 besar. Untuk lebih memperjelas bagaimana penggunaan $e$-kelurahan Manjahlega terdapat rincian rekapitulasi harian per kelurahan di Kecamatan Rancasari sebagai berikut :

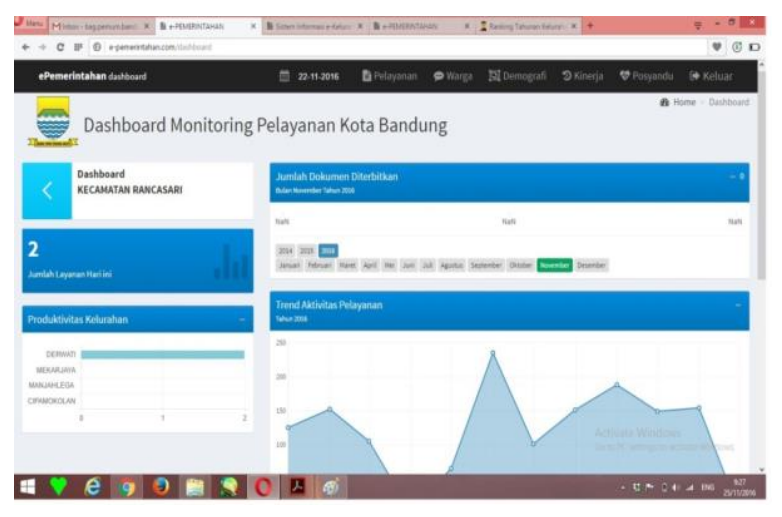

\section{Gambar 3 \\ Dashboard Monitoring \\ Pelayanan per Kelurahan}

Sumber : Data Bagian Pemerintahan Umum Kota Bandung 2016

Dari gambar 3 terlihat bahwa penerapan e-kelurahan dari 4 kelurahan di Kecamatan Rancasari hanya Kelurahan Derwati saja yang sudah menggunakan aplikasi $e$-kelurahan secara aktif. Sedangkan Kelurahan Manjahlega belum secara aktif dalam menggunakan aplikasi $e$-kelurahan. Secara mutu aplikasi sebetulnya aparatur kelurahan sudah diberikan berbagai kemudahan dengan aplikasi ini. Pelayanan kepada masyarakat menjadi lebih cepat dan mudah. Penyedia aplikasi $e$-kelurahan yaitu PT Telkom dan PT Portege sudah memberikan banyak kemudahan, dengan model web base, aparatur kelurahan tidak lagi mengalami kendala untuk menjalankan aplikasi $e$-kelurahan karena aplikasi ini bisa dibuka dimanpun baik dengan media PC ataupun Laptop. Ketika ada gangguan jaringan sudah tersedia mode offline yang memfasilitasi aparatur untuk tetap bisa melakukan pelayanan dan input data yang nantinya bisa terupdate ketika sudah online kembali. Aplikasi $e$-kelurahan dengan system cloud computing memberikan banyak kemudahan bagi penyelenggaraan pelayanan kepada masyarakat di tingkat kelurahan. Seluruh data yang diinput di aplikasi $e$ kelurahan dapat digunakan dalam jangka waktu yang panjang dengan tingkat validitas yang tinggi. Sehingga penyelenggaraan pelayanan kepada masyarakat dapat dilakukan sesuai dengan yang diharapkan.

\section{Efisiensi pelaksanaan $e$-Kelurahan}

Efisiensi dalam pelaksanaan $e$ kelurahan mencerminkan kepada rasio keluaran dibanding dengan masukan. Ukuran efisiensi termasuk mengenai penghematan, serta efisiensi dari segi waktu penyelesian pelayanan. Efisiensi yang dimaksud dalam tulisan ini adalah seluruh pelayanan yang menggunakan aplikasi $e$-kelurahan dapat diselesaikan tepat waktu dan dapat menghemat biaya apabila dibandingkan dengan proses manual. Berikut adalah hasil wawancara peneliti dengan Plt Kepala Seksi Pelayanan Kelurahan Manjahlega :“ Dengan adanya aplikasi $e$-kelurahan cukup menghemat anggaran apabila dibandingkan dengan sebelum dan sesudah menggunakan aplikasi $e$-kelurahan. Setiap kelurahan hanya membayar Rp.550.000 untuk sewa server setiap bulannya. Aplikasi ini sifatnya tidak beli putus, jadi ketika ada kerusakan bisa langsung diperbaiki. Dari segi penghematan waktu lebih cepat setelah menggunakan aplikasi $e$-kelurahan, namun di beberapa jenis pelayanan kami masih mengalami kendala dalam verifikasi." (Hasil Wawancara 10 November 2016)

Hal tersebut diperjelas oleh pernyataan dari operator $e$-kelurahan sebagai berikut : " Sebetulnya kami selalu aktif membuka aplikasi $e$-kelurahan, tetapi kalau pelayanan sedang banyak beberapa jenis pelayanan masih dilakukan secara manual karena di dalam mekanisme pelayanan ada beberapa tahap verifikasi yang tidak berjalan. Sehingga agar pelayanan tetap berjalan, kami terkadang masih backup dengan proses manual." (Hasil Wawancara 10 November 2016). Pernyataan dari operator diperkuat 
dengan data yang penulis peroleh dari screenshot dashboard pelayanan yang belum selesai berikut ini :

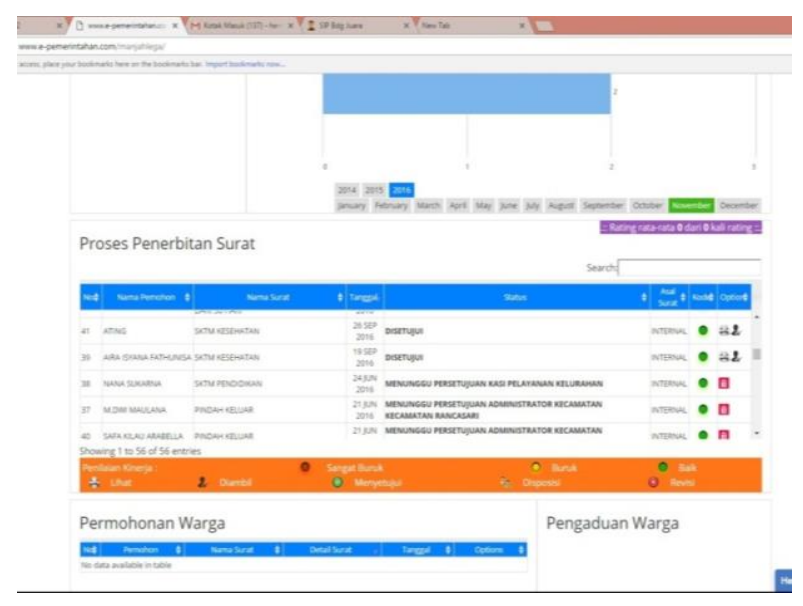

\section{Gambar 4}

Dashboard penerbitan surat yang belum terselesaikan melalui $\boldsymbol{e}$-kelurahan

Sumber : Data Kelurahan Manjahlega 2016

Apabila melihat screenshot dashboard penerbitan surat tersebut, ada beberapa jenis pelayanan yang belum terselesaikan sejak bulan Juni 2016 yaitu Penerbitan SKTM Pendidikan,dan Penerbitan Surat Pindah Keluar. Di dalam SOP Pelayanan Permohonan SKTM dan Surat Pindah Keluar terdapat verifikasi dari pihak kecamatan. Berikut adalah mekanisme pelayanan SKTM dan Surat Pindah Keluar.

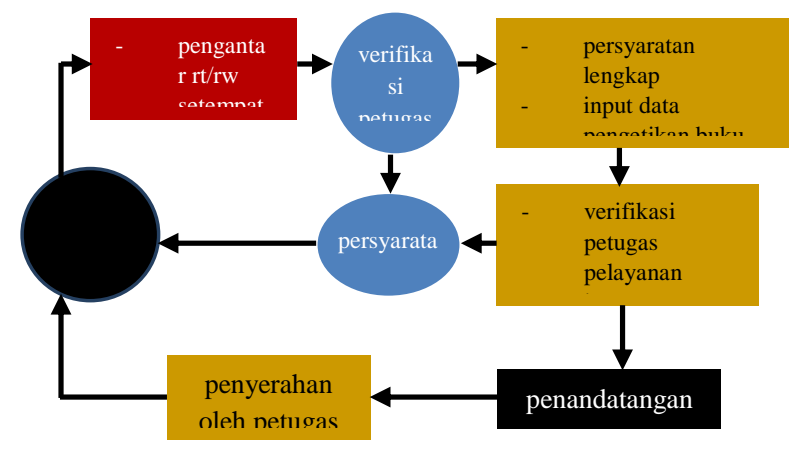

Gambar 5

Alur Pelayanan Permohonan SKTM \& Pindah Keluar

Sumber : Sumber : Data Kelurahan Manjahlega 2016

Dari gambar 5 alur tersebut terlihat bahwa didalam mekanisme permohonan
SKTM dan Pindah Keluar terdapat rantai verifikasi oleh Petugas pelayanan di tingkat Kecamatan. Verifikasi oleh petugas pelayanan di Kecamatan dilakukan ketika verifikasi oleh petugas Kelurahan sudah selesai dan seluruh persyaratan permohonan warga dinyatakan lengkap. Berdasarkan pengamatan penulis kendala yang dialami pada proses pelayanan yang belum selesai adalah karena keterbatasan Sumber Daya Manusia dalam hal ini terdapat beberapa jabatan kosong yaitu Kepala Seksi Pelayanan di Kelurahan Manjahlega yang meninggal dunia dan sementara digantikan dengan Plt Kepala Seksi Pelayanan yang masih menjabat jabatan lain sehingga pada penerapan $e$-kelurahan belum berjalan dengan maksimal. Selain itu untuk jabatan Kepala Seksi Pelayanan Kecamatan Rancasari dimana pejabat yang bersangkutan telah pensiun dan sementara digantikan oleh Plt Kepala Seksi Pelayanan. Kondisi sumber daya manusia di tingkat Kelurahan Manjahlega dan Kecamatan yang masih dijalankan oleh pejabat sementara, turut mempengaruhi pada proses pelaksanaan $e$ kelurahan. Ini terlihat dari tahapan verifikasi oleh Kecamatan yang tidak berjalan sebagaimana mestinya. Dengan adanya pejabat sementara yang menduduki posisi tersebut perlu adanya komunikasi yang lebih intensif serta koordinasi yang lebih efektif terkait proses pelayanan dengan aplikasi $e$ kelurahan.

\section{Kepuasan Warga Pengguna $e$-kelurahan Manjahlega}

Kepuasan masyarakat lingkungan kelurahan Manjahlega sebagai indikator dari efektivitas penerapan aplikasi $e$-kelurahan di Kelurahan Manjahlega. Kepuasan meliputi sikap karyawan, kelambanan, dan penanganan keluhan. Kepuasan yang dimaksud adalah apakah masyarakat sudah puas dengan pelayanan aparatur kelurahan ketika menggunakan $e$-kelurahan serta bagaimana sistem pengaduan yang diberikan kepada masyarakat. Berikut adalah hasil wawancara 
dengan Plt Kepala Seksi Pelayanan Kelurahan Manjahlega :

"Sejauh ini tanggapan masyarakat mengenai aplikasi e-kelurahan baik, masyarakat merasa dilayani dengan baik, keluhan-keluhan memang ada untuk beberapa jenis pelayanan, tapi masyarakat diberikan ruang untuk melakukan pengaduan sesuai degan mekanisme pengaduan yang ada, kami berupaya memegang teguh komitmen terhadap Moto Pelayanan dan Maklumat Pelayanan yang kami sepakati "(Hasil Wawancara 10 November 2016)

Berdasarkan pernyataan dari Kepala Seksi Pelayanan Kelurahan Manjahlega kepuasan masyarakat terhadap aplikasi ekelurahan baik, walaupun ada beberapa keluhan di jenis-jenis pelayanan tertentu. Aparatur Kelurahan selalu berupaya menjelaskan dan mensosialisasikan bahwa aplikasi ini akan selalu ditingkatkan, dan memiliki kebermanfaatan yang panjang. Di dalam setiap pelayanan yang diberikan aparatur Kelurahan Manjahlega berupaya memberikan pelayanan dengan mengedepankan 4 Motto Pelayanan Kelurahan Manjahlega yaitu Santun, Ikhlas, Akuntabel, dan Prima. Keempat motto tersebut senantiasa diterapkan oleh aparatur Kelurahan Manjahlega, termasuk dalam melaksanakan pelayanan dengan aplikasi $\underline{e}-$ kelurahan. Berikut penjelasan salah seorang warga Kelurahan Manjahlega yang berprofesi sebagai pegawai BUMN :" Pelayanan di kelurahan sudah cukup baik, semenjak adanya aplikasi $e$-kelurahan beberapa pelayanan pembuatan surat menjadi lebih cepat dan mudah. Terutama sikap dari pegawai kelurahan yang dapat memberikan penjelasan dengan baik mengenai aplikasi $e$ kelurahan."(Hasil wawancara 15 November 2016). Berdasarkan hasil wawancara tersebut terlihat bahwa masyarakat sudah merasa puas dengan pelayanan menggunakan aplikasi $e$ kelurahan, walaupun masih ada beberapa kekurangan dalam pelaksanaannya.

\section{Adaptasi aparatur terhadap penerapan aplikasi $e$-kelurahan}

Adaptasi dalam penerapan aplikasi $e$ kelurahan di Kantor Kelurahan Manjahlega menyangkut kemampuan organisasi untuk mengalihkan kemampuan sumberdaya dari aktivitas satu ke aktivitas yang lain guna menghasilkan produk \& pelayanan yang baru dan berbeda sesuai dengan tuntutan masyarakat. Organisasi perlu menginvestasikan tidak hanya teknologi dari metode produksi yang fleksibel tetapi juga dalam pengembangan kemampuan karyawan dalam mengoperasikan teknologi. Salah satu upaya yang dilakukan oleh Pemerintah Kota Bandung untuk meningkatkan kemampuan aparatur dalam penerapan aplikasi $e$ kelurahan adalah dengan mengadakan pelatihan $e$-kelurahan bersama dengan PT Telkom dan PT Potege, berikut adalah pelatihan yang diselenggarakan dari kurun waktu Tahun 2015-2016 :

\begin{tabular}{l|l|l|l}
\hline No & Tahun & Peserta & Materi Pelatihan \\
\hline 1 & $\begin{array}{l}\text { Juni } \\
2015\end{array}$ & $\begin{array}{l}\text { Operator e- } \\
\text { kelurahan } \\
\text { Kota } \\
\text { Bandung }\end{array}$ & $\begin{array}{l}\text { Tutorial Aplikasi } \\
\text { e-kelurahan }\end{array}$ \\
\hline 2 & $\begin{array}{l}\text { Juni } \\
2016\end{array}$ & $\begin{array}{l}\text { Operator e- } \\
\text { kelurahan } \\
\text { Kota } \\
\text { Bandung }\end{array}$ & $\begin{array}{l}\text { Pengembangan } \\
\text { Aplikasi e- } \\
\text { kelurahan }\end{array}$ \\
\hline
\end{tabular}

\section{Tabel 3 \\ Daftar Pelatihan e-Kelurahan Kota Bandung}

Sumber : Bagian Pemerintahan Umum Kota Bandung (2016)

Pemerintah Kota Bandung dalam hal ini Bagian Pemerintahan Umum Kota Bandung sebagai Leading Sector penerapan aplikasi $e$-kelurahan, senantiasa berupaya meningkatkan kemampuan aparatur kelurahan dalam meningkatkan operasional $e$-kelurahan. Operator dibekali materi teknis dan pengembangan yang meliputi cara-cara menginput data masyarakat terkait pembuatan Registrasi Surat, Surat Keterangan Domisili, Surat Keterangan Tidak Mampu, Surat 
Keterangan, Pengantar RT/RW, Surat Keterangan Kelahiran, Surat Keterangan Kematian, Surat Pengantar dan Template Dokumen. Pelatihan aplikasi $e$-kelurahan sudah dilakukan di tahun 2015 dan tahun 2016, untuk tahun 2017 direncanakan akan ada pelatihan dan sosialisasi kembali, berikut hasil wawancara dengan Pejabat Analis Kelurahan Bagian Pemerintahan Umum Kota Bandung : "Pelatihan sudah beberapa kali diadakan dan diikuti oleh operator-operator perwakilan kelurahan di Kota Bandung. Selain pelatihan yang diselenggarakan Bagian Pemerintahan Umum, setiap kelurahan juga diberi kesempatan untuk mengikuti pelatihan tambahan kepada PT Portege dengan biaya Rp100.000 per orang. Banyak sekali kemudahan-kemudahan yang diberikan untuk menjalankan aplikasi $e$-kelurahan, terlebih lagi sekarang PT Portege secara khusus membuka kantor cabang di Bandung untuk mempermudah ketika terjadi hambatan dalam pengoperasian $e$-kelurahan."(Hasil wawancara 25 November 2016). Hal senada juga diungkapkan Kepala Seksi Pelayanan Kelurahan Manjahlega sebagai berikut :"Pelatihan sudah beberapa kali diselenggarakan, dari Kelurahan Manjahlega selalu mengirim operator untuk ikut serta pada pelatihan tersebut. Operator Kelurahan Manjahlega selalu berupaya melaksanakan operasional $e$-kelurahan sesuai dengan pedoman yang ada." (Hasil Wawancara 10 November 2016)

Dari hasil wawancara tersebut dapat diketahui bahwa upaya pemerintah Kota Bandung untuk mengembangkan kemampuan aparatur dalam menjalankan aplikasi $e$ kelurahan sudah sangat baik yaitu dengan menyelenggarakan pelatihan kepada para operator dan membuka kesempatan setiap kelurahan untuk mengembangkan operasional $e$-kelurahan. Namun keikutsertaan pelatihan yang ada saat ini masih terbatas kepada operator, sedangkan pelatihan kepada aparatur yang berwenang melakukan verifikasi pada proses $e$-kelurahan belum secara intensif dilakukan. Kondisi kepegawaian Seksi
Pelayanan yang tentatif di Kecamatan Rancasari dan Kelurahan Manjahlega sedikit banyak turut mempengaruhi proses penyelesaian permohonan pelayanan dari masyarakat terutama dalam hal verifikasi. Oleh karena itu setiap jabatan seyogjanya dibekali pengetahuan mengenai penggunaan $e$-kelurahan beserta kewenangan dan hak aksesnya, sehingga ketika terjadi penggantian jabatan proses verifikasi permohonan pelayanan tetap berjalan sebagaimana mestinya.

\section{Pengembangan $e$-kelurahan}

Pengembangan yang dimaksud adalah melalui investasi sumber daya guna memenuhi tuntutan dan kebutuhan masyarakat baik dari aplikasi maupun sumber daya manusia. Apabila melihat dari model aplikasi $e$-kelurahan yang bebasis web base, tidak membutuhkan peralatan yang banyak, spesifik dan tidak perlu instalasi sehingga bisa dibuka dimana saja, baik PC ataupun laptop. Aplikasi $e$-kelurahan dengan sistem cloud computing atau komputasi awan memiliki kelebihan karena saat ini sudah menjadi trend baru di bidang komputasi, dimana berbagai pihak dapat mengembangkan aplikasi jenis ini. Dengan berbagai kemudahan tersebut harapannya $e$-kelurahan akan diajukan sebagai feeder data yang mencakup semua data-data kewilayahan seperti jumlah bangunan, jumlah bayi dan informasi lainnya. Berikut hasil wawancara dengan Jabatan Analis Kelurahan Bagian Pemerintahan Umum Kota Bandung :“ kedepan aplikasi ekelurahan akan dikembangkan menjadi ewarga yaitu portal yang mewadahi beberapa aplikasi termasuk e-posyandu dan aplikasi inovasi lain di wilayah Kota Bandung yang nantinya aplikasi-aplikasi ini akan hyperlink antara satu dengan yang lain"(Hasil wawancara 25 November 2016)

Berdasarkan pernyataan dari Analis Kelurahan Kota Bandung terlihat bahwa Pemerintah Kota Bandung akan terus mendorong inovasi dalam penyelenggaraan pelayanan kepada masyarakat. Terlebih lagi 
apabila melihat dari karakteristik warga Kota Bandung yang mayoritas sudah peka dengan perkembangan teknologi. Berbagai jenis pelayanan yang diberikan kepada masyarakat pun diharapkan dapat diberikan dengan lebih cepat dan mudah. Oleh karena itu pengembangan aplikasi sebagai sumber daya utama dalam pelaksanaan $e$-government sangat dibutuhkan.

\section{Kelangsungan hidup penerapan $e$ - Kelurahan}

Kelangsungan hidup sebagai salah satu indikator efektivitas penerapan $e$ kelurahan mencerminkan tanggung jawab organisasi dalam mengembangkan potensi $e$ kelurahan. Kelangsungan hidup yang dimaksud merujuk kepada bagaimana program $e$-kelurahan dapat bertahan dalam rangka memberikan pelayanan kepada masyarakat. Berikut hasil wawancara dengan Plt Kepala Seksi Pelayanan Kelurahan Manjahlega : "penerapan $e$-kelurahan Manjahlega dilaksanakan sesuai dengan Pedoman $e$-kelurahan di Kota Bandung, dari segi aplikasi dan operator diupayakan berjalan dengan optimal, begitu juga dengan penyerahan laporan rekapitulasi $e$-kelurahan bulanan kepada Bagian Pemerintahan Umum diusahakan selalu tepat waktu." (Hasil wawancara 10 November 2016)

Dari pernyataan Plt Kepala Seksi Pelayanan Kelurahan Manjahlega tersebut dapat diketahui bahwa Kelurahan Manjahlega berupaya untuk menerapkan $e$-kelurahan sesuai dengan yang semestinya baik dari segi aplikasi maupun sumber daya termasuk juga pada saat pelaporan. Berikut hasil wawancara dengan Analis Kelurahan Bagian Pemerintahan Umum Kota Bandung : "Program $e$-kelurahan Kota Bandung merupakan wujud dari harapan Bapak Walikota Bandung yang ingin membangun Bandung dengan Segitiga sama kaki yaitu inovasi, desentralisasi dan kolaborasi. Oleh karena itu Pemerintah Kota Bandung mengajak masyarakat untuk bersama-sama mengingatkan aparatur Kelurahan dalam pelaksanaan $e$-kelurahan dengan berbagai sosialisasi di tingkat kelurahan serta pemantauan pelaporan dari kelurahan." (Hasil wawancara 25 November 2016)

Berdasarkan hasil wawancara dengan Plt Kepala Seksi Kelurahan Manjahlega dan Pejabat Analis Kelurahan Bagian Pemerintahan Umum, terlihat bahwa upaya yang dilakukan untuk mempertahankan keberlangsungan $e$-kelurahan salah satunya adalah dengan sosialisasi dan pengawasan. Sosialisasi yang dimaksud adalah bagaimana menyampaikan program $e$-kelurahan secara berjenjang baik ke tingkat Kecamatan, Kelurahan serta masyarakat. Sampai dengan November 2016, sosialisasi sudah dilakukan dalam bentuk pertemuan bersama perwakilan RT dan RW. Sosialisasi $e$-kelurahan baik kepada aparatur maupun masyarakat, tujuannya adalah membuka wawasan dan merubah mindset serta kebiasaan yang terpaku pada proses pelayanan manual.

Hal lain yang tidak kalah penting adalah bagaimana pengawasan yang dilakukan oleh Bagian Pemerintahan Umum Kota Bandung sebagai Leading Sector penerapan aplikasi $e$-kelurahan. Sejauh ini pengawasan dilakukan dengan memantau penyerahan laporan rekapitulasi bulanan yang teridentifikasi melalui aplikasi Sistem Informasi Penilaian (SIP) Lurah dan Camat. Laporan bulanan ini merupakan salah satu indikator yang menunjukkan keberhasilan penerapan $e$-kelurahan. Ketika Lurah tidak melaporkan pelayanan $e$-kelurahan maka akan mempengaruhi Rangking Penilaian Lurah. Untuk periode tahun 2016 Kelurahan Manjahlega menduduki urutan Rangking ke 35 dari 151 Kelurahan di Kota Bandung. Prestasi ini dinilai masih belum sesuai dengan kondisi masyarakat Kelurahan Manjahlega yang mayoritas berlatar pendidikan minimal Sarjana dan sangat peka terhadap perkembangan teknologi. Terlebih lagi ketika melihat prestasi Kelurahan Manjahlega di Tahun 2016 yang meraih Juara 2 Lomba Pemberdayaan Kelurahan Se-Jawa Barat, yang membuktikan bahwa karakteristik 
masyarakat Kelurahan Manjahlega adalah aktif dan berkontribusi terhadap pengembangan tata kewilayahan di tingkat kelurahan.

\section{Pembahasan}

Dari hasil penelitian yang dilakukan penulis, ditemukan bahwa Penerapan $e$ kelurahan perlu didukung oleh sarana dan prasarana penunjang beberapa perangkat seperti komputer, server, dan aplikasi. Infrastuktur yang berkualitas dapat mempengaruhi keberhasilan pencapaian $e$ kelurahan. Berikut hasil wawancara dengan Plt Kepala Seksi Pelayanan Kelurahan Manjahlega : “ Sarana dan prasarana pendukung $e$-kelurahan di kantor Kelurahan Manjahlega sudah tersedia, yaitu 2 buah komputer dan untuk jaringan Kota Bandung bekerja sama dengan PT Telkom, pemilihan ini sangat tepat karena dari pengalaman yang ada kerjasama dengan PT Telkom merupakan server paling aman. Untuk mengakses website juga tergolong mudah karena $e$-kelurahan tersedia fitur offline sehingga ketika terjadi ganggungan data akan tetap aman." (Hasil Wawancara 10 November 2016). Pernyataan tersebut didukung oleh pengamatan peneliti yaitu terdapat 2 buah komputer dan jaringan, serta aplikasi. Instfrastruktur $e$-kelurahan di Kantor Kelurahan Manjahlega sudah memadai. Untuk mewujudkan penerapan ekelurahan memang perlu adanya kesiapan dari segi teknologi, jaringan dan pengelolaan yang andal dan merata di seluruh Kelurahan di Kota Bandung agar pelayanan kepada masyarakat berjalan dengan baik.

Pelaksanaan $e$-kelurahan tidak terlepas dari ketersediaan anggaran. Pengembangan $e$ kelurahan membutuhkan biaya dalam hal pembelian aplikasi, sewa server, pemeliharaan, dan pelatihan operator. Berikut hasil wawancara Plt Kepala Seksi Pelayanan Kelurahan Manjahlega."Penerapan $e$ kelurahan memakan biaya yang tidak terlalu mahal, setiap kelurahan hanya membayar Rp. 550.000/ bulan untuk sewa server dan ketika ada operator baru yang ingin dilatih, hanya membayar Rp. 100.000/ orang." (Hasil Wawancara 10 November 2016). Berdasarkan hasil wawancara tersebut, anggaran yang dibutuhkan untuk $e$-kelurahan tidak terlalu besar. Hal ini sebanding dengan manfaat yang dihasilkan dalam penerapan $e$-kelurahan. Dengan adanya $e$-kelurahan cukup menghemat waku dan biaya operasional pelayanan kepada masyarakat karena proses verifikasi yang biasanya harus dilakukan manual, saat ini bisa dilakukan hanya melalui aplikasi.

Salah satu tujuan dari keberhasilan $e$ kelurahan adalah bagaimana menciptakan tata kelola pemerintahan tingkat kelurahan yang transparan, akuntabel dan bebas dari korupsi. Oleh karena itu kemampuan aparatur sangat dibutuhkan dalam penerapan e-kelurahan. Berikut hasil wawancara dengan Plt Kepala Seksi Pelayanan Kelurahan Manjahlega : "Aparatur kelurahan Manjahlega yang terkait dengan $e$-kelurahan belum semua memahami dan mengerti operasional $e$-kelurahan. Namun kami memiliki seorang operator usia nya masih muda, walaupun latar belakang pendidikan bukan dari IT tetapi sangat mengikuti perkembangan teknologi" (Hasil Wawancara 10 November 2016)

Berdasarkan wawancara tersebut terlihat bahwa belum semua aparatur yang terkait dengan $e$-kelurahan memahami bagaimana cara menggunakan aplikasi $e$ kelurahan. Masih banyak aparatur yang tidak paham akan kondisi saat ini yang menuntut percepatan pengembangan pelayanan melalui teknologi. Masih ada beberapa pelayanan yang dilakukan secara manual karena aparatur beranggapan bahwa di saat-saat tertentu proses pelayanan manual lebih cepat dibandingkan dengan aplikasi $e$-kelurahan. Disini perlu adanya perubahan mindset dari aparatur Kelurahan bahwa yang utama adalah bagaimana mengembangkan $e$-kelurahan agar berjalan dengan baik bukan kembali mundur kepada proses pelayanan yang manual. Seperti yang dijelaskan oleh (Bigdeli, Kamal, \& De Cesare, 2013) bahwa organisasi publik perlu bergerak cepat dalam merespon 
kebutuhan masyarakat serta mengimbangi perkembangan teknologi di sektor swasta untuk bertahan dengan kecepatan yang sama.

Salah satu kendala penerapan $e$ kelurahan di Kelurahan Manjahlega ada adalah karena belum adanya penguatan dari sisi regulasi. Berikut hasil wawancara dengan Analis Kelurahan Bagian Pemerintahan Umum Kota Bandung : " Aplikasi $e$ kelurahan diterapkan untuk mendukung keberhasilan program smart city Kota Bandung dan sebagai salah satu implementasi $e$-government. Saat ini belum dibuat peraturan daerah mengenai $e$-kelurahan di Kota Bandung"( Hasil wawancara 25 November 2016)

Berdasarkan hasil wawancara tersebut diketahui bahwa sampai penulis melakukan penelitian, belum ada peraturan daerah Kota Bandung yang mengatur tentang penerapan $e$ kelurahan. Regulasi pelaksanaan $e$ government di Pemerintahan Daerah sebetulnya sudah mengacu pada Undangundang, peraturan pemerintah serta pedoman yang ada. Namun peraturan ini masih bersifat umum dan masih menimbulkan penafsiran yang berbeda-beda. Untuk itu dalam penerapan $e$-kelurahan diperlukan adanya produk hukum sebagai infrastruktur legal yang mendukung pendayagunaan $e$-kelurahan, agar pencapaian $e$-kelurahan di seluruh Kelurahan di Kota Bandung dapat terwujud sesuai dengan yang diharapkan.

Koordinasi memiliki peranan yang penting dalam penerapan $e$-kelurahan. Dengan adanya koordinasi pembagian tugas, wewenang dan tanggung jawab kegiatan akan berjalan dengan baik, termasuk koordinasi antara perangkat kelurahan dengan kecamatan dalam penerapan $e$-kelurahan. Namun sinergitas dalam koordinasi antar perangkat pemerintah tersebut belum terlaksana dengan optimal. Berikut hasil wawancara dengan Plt Kepala Seksi Pelayanan Kecamatan Rancasari : "Ada beberapa pelayanan masyarakat di $e$ kelurahan seperti pembuatan KK dan SKTM yang membutuhkan verifikasi dari kecamatan, namun kami mengalami kendala mengenai jaringan. Pertemuan khusus dengan kelurahan terkait hal ini belum dilakukan".(Hasil wawancara 15 November 2016)

Dari hasil wawancara tersebut penulis menyimpulkan bahwa koordinasi antara perangkat Kelurahan dan Kecamatan dalam rangka penerapan $e$-kelurahan belum berjalan dengan baik. Pertemuan untuk membahas $e$ kelurahan belum dilakukan sehingga masih ada perbedaan persepsi dalam operasional ekelurahan. Untuk mencapai tujuan ekelurahan pihak Kecamatan dan Kelurahan perlu duduk bersama, menyamakan persepsi sehingga penerapan $e$-kelurahan dapat tercapai.

\section{PENUTUP}

\section{Kesimpulan Dan Rekomendasi}

E-kelurahan Kota Bandung merupakan program inovatif serta visioner yang sudah diterapkan di 151 Kelurahan di Kota Bandung. Beberapa kelurahan sudah menerapkan $e$-kelurahan dengan baik, namun masih ada beberapa kelurahan yang belum optimal dalam penggunaan aplikasi ini, seperti yang terjadi di Kelurahan Manjahlega. Penerapan $e$-kelurahan sudah berjalan di Kelurahan Manjahlega, namun belum semua jenis fitur pelayanan diselenggarakan dengan aplikasi $e$-kelurahan. Di satu sisi dengan $e$ kelurahan meningkatkan keakuratan output pelayanan, waktu pelayanan menjadi lebih cepat, tapi di sisi lain penerapan $e$-kelurahan belum diimbangi dengan kesiapan perangkat kelurahan dimana masih ada jenis pelayanan yang diselenggarakan secara manual.

Kendala yang dialami oleh Kelurahan Manjahlega dalam menerapkan $e$-kelurahan adalah mengenai keterbatasan sumber daya manusia baik dari segi kuantitas maupun pemahaman aparatur mengenai operasional $e$ kelurahan. Selain itu dari sisi regulasi belum ada peraturan daerah yang mengatur mengenai $e$-kelurahan di Kota Bandung serta sinergitas dalam koordinasi antara Kelurahan dan kecamatan belum berjalan dengan optimal. Selain itu aspek kepercayaan masyarakat kepada pemerintah dapat menjadi 
penguat bagi keberlanjutan e-governement di daerah karena dengan kepercayaan dari masyarakat dapat memberikan kemudahan kepada pemerintah sebagai penyelenggara $e$ government.

E-kelurahan sebagai salah satu aplikasi pendukung smart city yang bertujuan mempercepat, mempermudah otomasi administrasi pelayanan di tingkat kelurahan perlu adanya pengembangan yang berkesinambungan terkait aplikasi $e$ kelurahan juga peningkatan kemampuan aparatur kelurahan. Bagian Pemerintahan Umum Kota Bandung sebagai leading sector yang melakukan pengawasan penerapan $e$ kelurahan di Kota Bandung senantiasa melakukan pemantauan perkembangan ekelurahan melalui aplikasi e-kelurahan dan Sistem Informasi Penilaian Lurah dan Camat. Penilaian ini dapat menentukan rangking Lurah dan Camat di seluruh wilayah Kota Bandung.

\section{Rekomendasi}

Perlu adanya pelatihan dan sosialisasi lebih lanjut kepada aparatur kelurahan, tidak hanya kepada operator tetapi juga kepada perangkat kelurahan serta perangkat kecamatan. Dengan adanya sosialisasi yang menyeluruh, aparatur dapat memahami alur pelayanan e-kelurahan terutama dalam proses verifikasi yang melibatkan Kecamatan. Sosialisasi juga diberikan kepada masyarakat agar masyarakat dapat mengetahui dan berpartisipasti aktif di dalam penerapan $e$ kelurahan. Efektivitas $e$-government juga kan mudah terwujud apabila ada penguatan dari sisi regulasi, terlebih lagi banyak pelayanan yang melibatkan koordinasi dengan Kecamatan. Dengan adanya produk hukum yang mendukung e-kelurahan, aparatur Kelurahan dan Kecamatan dapat memberikan kontribusi sesuai tugas dan kewenangannya. Selain itu peningkatan koordinasi dan kolaborasi antara perangkat Kelurahan, Kecamatan dan Bagian Pemerintahan Umum Kota Bandung. Hal ini dapat dilakukan dengan cara diadakan pertemuan rutin untuk melakukan pemantauan dan membahas kendala yang dihadapi dalam penerapan $e$ kelurahan.

\section{DAFTAR PUSTAKA}

Abu-Shanab, E. A. (2017). E-government familiarity influence on Jordanians' perceptions. Telematics and Informatics, 34(1), $103-113$. https://doi.org/10.1016/j.tele.2016.05.00 1

Bigdeli, A. Z., Kamal, M. M., \& De Cesare, S. (2013). Electronic information sharing in local government authorities: Factors influencing the decision-making process. International Journal of Information Management, 33(5), 816-830. https://doi.org/10.1016/j.ijinfomgt.2013. 05.008

Buffat, A. (2015). Street-Level Bureaucracy and E-Government. Public Management Review, 17(1), 149-161. https://doi.org/10.1080/14719037.2013.7 71699

de Araujo, M. H., \& Reinhard, N. (2013). Factors influencing the Use of Electronic Government Services in Brazil. EGOV/ePart Ongoing Research, 140149. https://doi.org/10.5700/579

Gedeian, A. (1991). Organization Theory and Design. University of Colorado at Denve.

Gibson, James L; Ivancecih, John M.; Donnelly, J. H. (1996). Organisasi : perilaku, struktur (1st ed.). Jakarta: Bina Rupa Aksara.

Hertiarani, W. (2016). IMPLEMENTASI KEBIJAKAN E-SAMSAT DI JAWA BARAT. Jurnal Ilmu Administrasi: Media Pengembangan Ilmu Dan Praktek Administrasi, 13(3), 419-440. Retrieved 
from

http://stialanbandung.ac.id/ojs/index.php/ jia/article/view/102

Indrajit, R. E. (2002). Electronic Government: Strategi Pembangunan dan Pengembangan Sistem Pelayanan Publik Berbasis Teknologi Digital. Yogjakarta: Andi.

Miftah. (2015). Kota Bandung Terpilih Menjadi Finalis Smart City Di Barcelona. Retrieved from https://portal.bandung.go.id/posts/2015/1 1/19/bVev/kota-bandung-

Moleong, L. J. (2001). Metodologi Penelitian Kualitatif. Bandung: PT Remaja Rosdakarya.

Nam, T. (2014). Determining the type of egovernment use. Government Information Quarterly, 31(2), 211-220. https://doi.org/10.1016/j.giq.2013.09.006

Song, M., \& Guan, Y. (2015). The electronic government performance of environmental protection administrations in Anhui province, China. Technological Forecasting and Social Change, 96, 7988.

https://doi.org/10.1016/j.techfore.2014.1 0.001

Sosiawan, E. A. (2008). Tantangan Dan Hambatan Dalam Implementasi EGovernment Di Indonesia. Seminar Nasional Informatika, 2008(semnasIF), 99-108.

Venkatesh, V., Thong, J. Y. L., Chan, F. K. Y., \& Hu, P. J. H. (2016). Managing citizens' uncertainty in e-government services: The mediating and moderating roles of transparency and trust. Information Systems Research, 27(1), 87-111. https://doi.org/10.1287/isre.2015.0612 